Association for Information Systems AIS Electronic Library (AISeL)

PACIS 2001 Proceedings

Pacific Asia Conference on Information Systems

(PACIS)

December 2001

\title{
Managing Knowledge in Enterprise Systems
}

Roy Chan

Queensland University of Technology

Michael Rosemann

Queensland University of Technology

Follow this and additional works at: http://aisel.aisnet.org/pacis2001

\section{Recommended Citation}

Chan, Roy and Rosemann, Michael, "Managing Knowledge in Enterprise Systems" (2001). PACIS 2001 Proceedings. 64.

http://aisel.aisnet.org/pacis2001/64

This material is brought to you by the Pacific Asia Conference on Information Systems (PACIS) at AIS Electronic Library (AISeL). It has been accepted for inclusion in PACIS 2001 Proceedings by an authorized administrator of AIS Electronic Library (AISeL). For more information, please contact elibrary@aisnet.org. 


\title{
Managing Knowledge in Enterprise Systems
}

\author{
Roy Chan, Michael Rosemann \\ Information Systems Management Research Center \\ Queensland University of Technology \\ Brisbane, Australia \\ \{rw.chan|m.rosemann\}@qut.edu.au
}

\begin{abstract}
Enterprise Systems are formidable and powerful information systems that have positioned themselves as a landmark in the evolution of Information Technology. The selection, implementation, use and continuous change of Enterprise Systems (ES) (e.g. mySAP.com) require a great amount of knowledge and experience. Due to the lack of inhouse ES knowledge and the high costs of engaging experienced implementation consultants, organizations realize the need to better leverage their knowledge resources. Managing this knowledge is increasingly important with the second wave of ES projects focusing E-Business applications like Customer Relationship Management (CRM) and Supply Chain Management (SCM). These new applications embrace an open-integration strategy that will incorporate and support other vendors' applications as part of its Internet-based enterprise computing platform. This paper proposes a framework for managing knowledge in Enterprise Systems. The framework draws its strength from meta-case studies and comprehensive literature analyses, which is consolidated into a three-dimensional framework.
\end{abstract}

\section{The Significance of Enterprise Systems}

Enterprise Systems (ES) (synonyms are Enterprise Resource Planning (ERP), Enterprisewide Systems and Enterprise Application Systems) can be defined as customizable, standard application software which includes integrated business solutions for the core processes (e.g. production planning and control, warehouse management) and the main administrative functions (e.g. accounting, human resource management) of an enterprise (Rosemann 1999). In order to configure and use ES efficiently, components like implementation tools (procedural models, reference information models, customizing guidelines, project management software), workflow functionality, tools for the development of add-on modules and system administration, and office suites are usually embedded.

The new economy is now heavily focused on the use of Internet to conduct businesses. To date, ES vendors, as well as consulting services, have extended their services to applications such as Supply Chain Management (SCM), Customer Relationship Management (CRM), and other e-Business solutions.

Currently, the main ES vendors are SAP, J. D. Edwards, Oracle and PeopleSoft. The Gartner Group (Gartner Group 1999) forecasts that the ES market will be greater than $\$ 20$ billion by 2002 (with a probability of $80 \%$ ). More than $50 \%$ of this will be ES 
service revenue, while the total ES license revenue will cover approx. \$9 billion. They estimate that more than 90 percent of Fortune 500 enterprises have purchased a module or a set of modules from an ES vendor. 50 percent have made a commitment to one vendor, while only less than 20 percent went actually live. They also estimate that the SME market is the main customer group as more than $50 \%$ of these enterprises still haven't selected a next-generation ES. For 2000 (2001, 2002) the Gartner Group anticipates a market growth of $22 \%(25 \%, 28 \%)$. All these figures show that ESinitiatives are among the biggest investments enterprises are currently conducting.

\section{The Need to Manage Knowledge Resources}

Implementing comprehensive IT applications like Enterprise Systems is a knowledgeintensive task. As such, it requires a great amount of experience from a wide range of people such as representatives from business departments, technical specialists from the IT department and project managers within the organization to external business and implementation consultants. Organizations implementing Enterprise Systems recognize this and find that Knowledge Management is strategically advantageous as it seeks to deal with the problem of leveraging knowledge resources in an organization. There is strong motivation for better leveraging ES implementation knowledge and making this knowledge available to those involved in the ongoing management of the system. "Having made costly errors by disregarding the importance of knowledge, many firms are now struggling to gain a better understanding of what they know, what they need to know, and what to do about it" (Davenport 1998).

While most existing ES literature have focused on the types of knowledge, methodologies and critical success factors required for the implementation of ES software (Bancroft 1996, Clemons 1999, Kirchmer 1999, Mahrer 1999, Scott 1999, Slooten, Yap 1999, Sumner 1999), it is noticed that they have not taken aspects of knowledge management into account. Knowledge resources can be better managed by having the transparency about what knowledge is required at which point in time during the implementation phase and where the knowledge resides. With this knowledge at hand, managers and implementation consultants can more effectively select, implement, use and upgrade the system. Furthermore, the ES vendors could provide a better guidance throughout the implementation process. This paper demonstrates how this flux of different kinds of knowledge can be structured to gain a positive influence over the entire success of the project.

\section{Types of Knowledge Required for the Management of Enterprise Systems}

Managing an Enterprise System requires a wide range of knowledge. In order to develop with a list of the required areas of knowledge for the ES management, an intensive literature review was conducted. This review included case studies and papers discussing the critical success factors for the ES implementation (Bancroft 1996, Clemons 1999, Davenport 1996, Gable et al. 1997, Gable 1998, Gable et al. 1998, Gable, Stewart 1999, Mahrer 1999, Scott 1999, Slooten, Yap 1999, Sumner 1999). The areas of knowledge that are mentioned are similar and the repetitions of the need for this knowledge from the case studies emphasize the need for knowledge to be made explicit. However, it is necessary 
to organize these areas of knowledge into a more manageable form. From the meta-case studies of the literature reviewed, five different types of knowledge are clearly identified and distilled for the successful management of ES software. These types of knowledge to be taken in mind are:

- Business knowledge

- Technical knowledge

- Product knowledge

- Company-specific knowledge

- Project knowledge

The following table shows the distillation of the types of knowledge required for managing Enterprise Systems and ensuring their success in operations and future developments. Through the integration and the identification of the knowledge types, they are described in the following context to ensure a "common language" that ES stakeholders can use to enable them to visualize these competencies and increase the visibility of their business processes. 


\begin{tabular}{|c|c|c|c|c|c|c|c|}
\hline \begin{tabular}{|l|} 
Meta \\
Study
\end{tabular} & & $\begin{array}{l}\text { No of studies/ } \\
\text { organizations } \\
\text { conducted }\end{array}$ & Business & Technical & Product & Company-specific & Project Management \\
\hline 1 & $\begin{array}{l}\text { "Critical Success } \\
\text { Factors in Enterprise } \\
\text { Wide Information } \\
\text { Management } \\
\text { Systems Projects" } \\
\text { Sumner(1999) }\end{array}$ & 4 case studies & $\begin{array}{l}\text { "obtain analysts with } \\
\text { "business" and } \\
\text { technology } \\
\text { knowledge. }\end{array}$ & $\begin{array}{l}\text { - "training and support } \\
\text { required to overcome } \\
\text { technical and } \\
\text { procedural challenges } \\
\text { in design and } \\
\text { implementation" } \\
\text { - "knowledge of the } \\
\text { business processes, } \\
\text { as well as an } \\
\text { understanding of the } \\
\text { technical aspects" } \\
\end{array}$ & $\begin{array}{l}\text { - "emphasize } \\
\text { reporting, including } \\
\text { custom report } \\
\text { development, use of } \\
\text { report generators" }\end{array}$ & $\begin{array}{l}\text { "Obtain and retain } \\
\text { team members with } \\
\text { knowledge of the } \\
\text { business } \\
\text { processes" }\end{array}$ & $\begin{array}{l}\text { - "Obtain top } \\
\text { management support } \\
\text { for the project" } \\
\text { - "bring all 'related' } \\
\text { projects together and } \\
\text { manage them" }\end{array}$ \\
\hline 2 & $\begin{array}{l}\text { "A Critical Success } \\
\text { Factor Model For } \\
\text { Enterprise Resource } \\
\text { Planning } \\
\text { Implementation" } \\
\text { Holland, Light and } \\
\text { Gibson(1999) }\end{array}$ & 5 case studies & $\begin{array}{l}\text { - "Held numerous } \\
\text { workshops to } \\
\text { examine the generic } \\
\text { business processes" } \\
\text { - "felt important to } \\
\text { address soft issues } \\
\text { and an emphasis was } \\
\text { placed on change } \\
\text { management" } \\
\end{array}$ & & $\begin{array}{l}\text { "technical expertise } \\
\text { for software } \\
\text { configuration was } \\
\text { sought from } \\
\text { experienced SAP } \\
\text { consultants" }\end{array}$ & $\begin{array}{l}\text { "users encouraged } \\
\text { to raise issues } \\
\text { particularly about } \\
\text { the design of } \\
\text { business processes } \\
\text { and their own roles } \\
\text { in the organization" }\end{array}$ & $\begin{array}{l}\text { - "Clear schedule plan } \\
\text { divided into phases } \\
\text { organized around the } \\
\text { design of common } \\
\text { business processes" } \\
\text { - "The project had } \\
\text { clearly defined phases } \\
\text { and kept to the original } \\
\text { plan" } \\
\end{array}$ \\
\hline 3 & $\begin{array}{l}\text { "Implementing ERP } \\
\text { Information Systems } \\
\text { using SAP" } \\
\text { Slooten and } \\
\text { Yap(1999) }\end{array}$ & 1 organization & $\begin{array}{l}\text { "problems of scope } \\
\text { creep could have } \\
\text { been avoided when a } \\
\text { conceptual model (of } \\
\text { current business } \\
\text { processes) has been } \\
\text { designed before } \\
\text { implementation" } \\
\end{array}$ & & $\begin{array}{l}\text { - "lack of knowledge, } \\
\text { experience and skills } \\
\text { of SAP/R3" }\end{array}$ & & $\begin{array}{l}\text { "large size of projects, } \\
\text { complexity, time } \\
\text { pressure" }\end{array}$ \\
\hline 4 & $\begin{array}{l}\text { "The FoxMeyer } \\
\text { Drugs' Bankruptcy: } \\
\text { Was it a failure of } \\
\text { ERP?" } \\
\text { Scott(1999) }\end{array}$ & 1 case study & & $\begin{array}{l}\text { "the execution of the } \\
\text { project was an issue } \\
\text { due to the shortage of } \\
\text { skilled and } \\
\text { knowledgeable } \\
\text { personnel"(ref to } \\
\text { warehouse } \\
\text { automation) }\end{array}$ & $\begin{array}{l}\text {-FoxMeyer did not } \\
\text { have the necessary } \\
\text { skills in-house and } \\
\text { was relying solely on } \\
\text { their consultants to } \\
\text { implement R/3 and } \\
\text { integrate the ERP } \\
\text { with an automated } \\
\text { warehouse system } \\
\end{array}$ & $\begin{array}{l}\text { "There was a } \\
\text { definite morale } \\
\text { problem among the } \\
\text { warehouse } \\
\text { employees" }\end{array}$ & $\begin{array}{l}\text { - The environment } \\
\text { quadrant of the risk } \\
\text { framework includes } \\
\text { issues over which } \\
\text { project management[in } \\
\text { FoxMeyer] has little or } \\
\text { no control }\end{array}$ \\
\hline
\end{tabular}




\begin{tabular}{|c|c|c|c|c|c|c|c|}
\hline \begin{tabular}{|l|} 
Meta \\
Study
\end{tabular} & & $\begin{array}{l}\text { No of studies/ } \\
\text { organizations } \\
\text { conducted }\end{array}$ & Business & Technical & Product & Company-specific & Project Management \\
\hline 5 & \begin{tabular}{|l|} 
"Differences in Critical \\
Success Factors in \\
ERP Systems \\
Integration in \\
Australia and China: \\
A Cultural Analysis" \\
Shanks, Parr, Hu, \\
Corbitt, Thanasankit \\
and Seddon(2000)
\end{tabular} & 2 case studies & $\begin{array}{l}\text { "both technical } \\
\text { knowledge about the } \\
\text { ERP system and its } \\
\text { reference models and } \\
\text { knowledge about its } \\
\text { operation and use for } \\
\text { IT and business } \\
\text { people" }\end{array}$ & $\begin{array}{l}\text { - "Data accuracy: data } \\
\text { loaded from existing } \\
\text { legacy systems must } \\
\text { be of high quality" }\end{array}$ & $\begin{array}{l}\text { - "Minimal } \\
\text { customisation: } \\
\text { minimising the scope } \\
\text { of the ERP system } \\
\text { implementation and } \\
\text { the amount of } \\
\text { customisation and } \\
\text { option selection" }\end{array}$ & $\begin{array}{l}\text { - "Cultural issues in } \\
\text { Information } \\
\text { Systems } \\
\text { Implementation - } \\
\text { influence on } \\
\text { organization, } \\
\text { organization } \\
\text { behaviour" }\end{array}$ & $\begin{array}{l}\text {-Clear goals: the } \\
\text { project must have } \\
\text { clearly defined and well } \\
\text { understood goals" } \\
\text { - "Project management: } \\
\text { a detailed project plan } \\
\text { related to the project } \\
\text { goals should be } \\
\text { defined" }\end{array}$ \\
\hline 6 & $\begin{array}{l}\text { "The ERP Revolution: } \\
\text { Surviving Versus } \\
\text { Thriving" } \\
\text { Ross(1998) }\end{array}$ & 15 organizations & $\begin{array}{l}\text { - "didn't have clear } \\
\text { performance metrics } \\
\text { and expectations for } \\
\text { their ERPs were } \\
\text { unable to determine } \\
\text { whether they were } \\
\text { benefiting from the } \\
\text { implementation" } \\
\text { - "business cases for } \\
\text { ERP implementations } \\
\text { were vague - often } \\
\text { referring to the need } \\
\text { for a solid } \\
\text { infrastructure without } \\
\text { quantifying } \\
\text { anticipated business } \\
\text { benefits" }\end{array}$ & $\begin{array}{l}\text { "system was } \\
\text { slow...some } \\
\text { transactions couldn't } \\
\text { be entered...working } \\
\text { crazy hours just to } \\
\text { catch up with data } \\
\text { entry" }\end{array}$ & $\begin{array}{l}\text { "Several } \\
\text { respondents noted } \\
\text { that their ERP was } \\
\text { an effective on-line } \\
\text { transaction } \\
\text { processing system, } \\
\text { but not a } \\
\text { management support } \\
\text { system. Thus, the } \\
\text { increased availability } \\
\text { of data didn't } \\
\text { translate into } \\
\text { management } \\
\text { information" -> } \\
\text { respondents might } \\
\text { not have understood } \\
\text { the functionality of } \\
\text { the system } \\
\end{array}$ & $\begin{array}{l}\text { - "ERPs require that } \\
\text { employees } \\
\text { understand general } \\
\text { business processes } \\
\text { well beyond their } \\
\text { immediate } \\
\text { responsibilities. " } \\
\text { - "Employees who } \\
\text { had difficulty } \\
\text { grasping how their } \\
\text { behaviors could } \\
\text { affect operations } \\
\text { several processes } \\
\text { removed from theirs } \\
\text { could introduce } \\
\text { contaminated data } \\
\text { into the system." }\end{array}$ & $\begin{array}{l}\text { - "communicated goals } \\
\text { and established } \\
\text { program scope" }\end{array}$ \\
\hline 7 & $\begin{array}{l}\text { "The Identification of } \\
\text { Necessary Factors for } \\
\text { Successful } \\
\text { Implementation of } \\
\text { ERP Systems" } \\
\text { Parr, Shanks and } \\
\text { Darke(2000) }\end{array}$ & $\begin{array}{c}42 \\
\text { implementation } \\
\text { projects with } 10 \\
\text { senior staff } \\
\text { members }\end{array}$ & $\begin{array}{l}\text { - "business should } \\
\text { adopt the processes } \\
\text { and options built into } \\
\text { the ERP" } \\
\text { - "members of the } \\
\text { company who are } \\
\text { released to provide } \\
\text { the business } \\
\text { expertise which forms } \\
\text { the foundation for the } \\
\text { new system } \\
\text { configuration" }\end{array}$ & & $\begin{array}{l}\text { "need to choose } \\
\text { minimal } \\
\text { customization of the } \\
\text { ERP" }\end{array}$ & $\begin{array}{l}\text { - "need an overview } \\
\text { of company } \\
\text { processes" }\end{array}$ & $\begin{array}{l}\text { - "best people full time } \\
\text { on the project team" } \\
\text { - "projects with smaller } \\
\text { scope and functionality } \\
\text { were likely to be more } \\
\text { successful than more } \\
\text { complex ones" } \\
\text { - "definition of scope and } \\
\text { goals, roles and } \\
\text { responsibilities" }\end{array}$ \\
\hline
\end{tabular}

Table 1. Types of Knowledge Required for Enterprise Systems 
Business knowledge covers the business issues in the management of Enterprise Systems. Most of the attributes of this dimension should be addressed before the actual implementation of ES in an organization. Business knowledge includes:

- functional knowledge in areas like general ledger accounting, purchasing, sales, human resource management, or strategic planning,

- organizational knowledge like business process management, communication policies, or document management,

- educational knowledge and knowledge about enterprise culture, social norms and practices.

Technical knowledge represents knowledge that is necessary in conjunction with the selection and use of database management software, network management, add-on programming, client-server-architectures, performance measurement, etc.

Product knowledge reflects the need for knowledge specific for a unique ES solution. Most ES solutions are comprehensive packages with a high degree of complexity. Consequently, Enterprise Systems became an area with an enormous importance of product-specific knowledge. This area of knowledge includes among others the understanding of the architecture of the product, knowledge about its functionality and constraints of applications, which often has to be limited due to the comprehensive approach, the implementation methodology, the release strategy or knowledge about the ES-specific programming language (like SAP's ABAP). Thus, this area of knowledge combines from a product-individual point-of-view business, technical and projectmanagement knowledge.

Company-specific knowledge. ES software is selected, implemented, used and changed in a specific company with individual characteristics and an individual organizational population. The knowledge type company-specific knowledge takes this into account. ES cannot be managed successfully without having a precise understanding of these company individual factors. This is the reason why the participation of the end users is a critical success factor for ES implementation projects.

Project management knowledge covers the management of human resources, time and cost to accomplish the objectives of a project. The implementation of an Enterprise System in an organization often requires project management for a time between 6 to 24 months. Project management involves planning, organizing and controlling a project with various time and cost constraints, and gathering senior management support. It also seeks to achieve outputs such as milestones and objectives (Weiss, Wysocki 1992).

Further areas of knowledge. Usually different project participants have the five types of the required ES knowledge. Consequently, communication, coordination and cooperation knowledge is required in order to integrate the five types of knowledge. It is obvious, that even if the five types of knowledge (business, technical, product, company, project) are available in a project, the missing capability to efficiently interact between the involved knowledge owners might be a reason for a project failure. One possible reason is that it takes a significant amount of time to develop the required communication, coordination and cooperation knowledge or to get the knowledge from different project members. More importantly, this area of knowledge includes the "people" factor. In 
Chan(1999), the "people" dimension in the ES perspective are identified as three key players of vendors, consultants and clients. In this regard, knowledge management activities can only be possible by active participation of the key players. The vendors seek to assist clients in rapid implementation of the ES, understanding system requirements and catering for future products and services for the clients, the consultants are involved in transferring the knowledge to the clients and assisting in streamlining implementation, the clients seek reap benefits of costs as well as retaining ES-knowledge within the organization.

\section{Activities required for Knowledge Creation and Process Innovation}

While the definition of Knowledge Management remains pervasive and perhaps elusive, much literature has also been written in the field of knowledge management. This paper will not cover the various aspects of knowledge management but view it through the lens of a Knowledge Lifecycle paradigm and focus on activities that are carried out to enable knowledge creation and process innovation. In order to distill a set of activities required to assist in knowledge management, this paper uses an existing Knowledge Lifecycle framework described in earlier publications by the authors(Rosemann and Chan 2000, Chan 1999). This framework identifies the activities that are conducted in the respective ES literature. The framework describes a set of activities that suggests a strict sequence of identifying $\rightarrow$ creating $\rightarrow$ transferring $\rightarrow$ storing $\rightarrow$ re-using $\rightarrow$ unlearning knowledge. However, further links between these different tasks exist, which are not depicted due to the complexity in the cardinality of the relationships. The co-relations between each tasks are complicated and the relationship between one and another are by far intricate.

The following diagram shows a basal set of activities that are associated with the Knowledge Lifecycle.

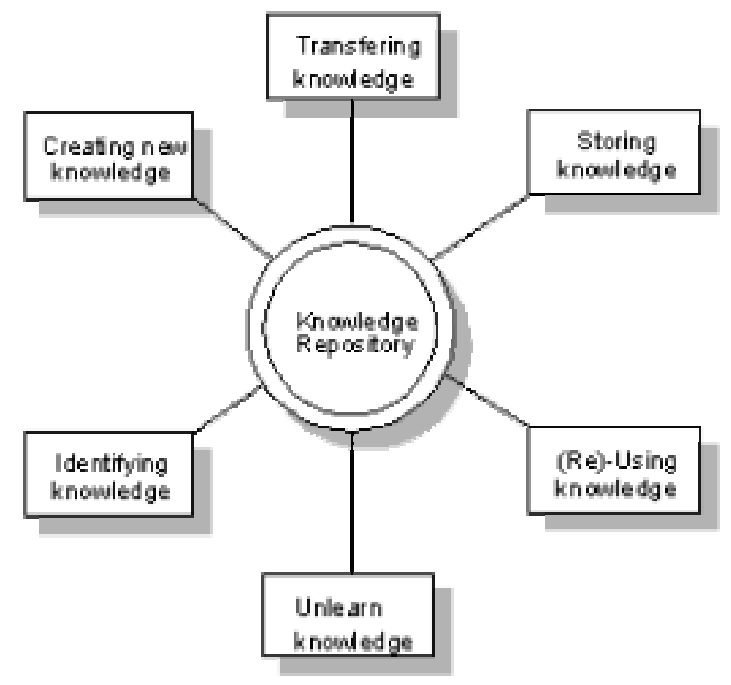

Figure 1. Activities in the Knowledge Lifecycle 
From these set of activities, the following table displays the relevant quotes in the ES literature that strongly suggest a need to manage the knowledge. It is evidently seen that the activities required for knowledge management are covered to a certain extent. This subliminal quotes are interpreted in the authors' perspective. However, further research is being conducted to confirm these types of activities and the types of knowledge with the espoused authors in the literature review through the means of a meta-analysis methodology.

\begin{tabular}{|c|c|c|c|}
\hline $\begin{array}{l}\text { Meta } \\
\text { Study }\end{array}$ & & Evidence & $\begin{array}{c}\text { Knowledge Lifecycle } \\
\text { activities }\end{array}$ \\
\hline 1 & $\begin{array}{l}\text { "Critical Success Factors in } \\
\text { Enterprise Wide Information } \\
\text { Management Systems } \\
\text { Projects” } \\
\text { Sumner(1999) }\end{array}$ & $\begin{array}{l}\text { - obtain and retain members with knowledge of } \\
\text { the business processes, as well as an } \\
\text { understanding of the technical aspects" }\end{array}$ & Store Knowledge \\
\hline 2 & \begin{tabular}{|l|} 
"A Critical Success Factor \\
Model For Enterprise Resource \\
Planning Implementation" \\
Holland, Light and \\
Gibson(1999)
\end{tabular} & $\begin{array}{l}\text { - "Held numerous workshops to examine the } \\
\text { generic business processes involving } 150 \text { staff" } \\
\text { "Identified } 30 \text { main processes and then defined } \\
\text { them in detail" }\end{array}$ & Identify Knowledge \\
\hline 3 & \begin{tabular}{|l|} 
"Implementing ERP Information \\
Systems using SAP" \\
Slooten and Yap(1999)
\end{tabular} & n.a. & n.a. \\
\hline 4 & $\begin{array}{l}\text { "The FoxMeyer Drugs' } \\
\text { Bankruptcy: Was it a failure of } \\
\text { ERP?" } \\
\text { Scott(1999) }\end{array}$ & $\begin{array}{l}\text { "Foxmeyer needed to ensure that project } \\
\text { knowledge was transferred to them from the } \\
\text { consultants so that they could develop in-house } \\
\text { skills for maintenance of the system after the } \\
\text { consultants left" }\end{array}$ & $\begin{array}{l}\text { Knowledge Transfer } \\
\text { Knowledge Re-use }\end{array}$ \\
\hline 5 & \begin{tabular}{|l|} 
"Differences in Critical Success \\
Factors in ERP Systems \\
Integration in Australia and \\
China: A Cultural Analysis" \\
Shanks, Parr, Hu, Corbitt, \\
Thanasankit and \\
Seddon(2000)
\end{tabular} & $\begin{array}{l}\text {-The collective nature of Chinese society } \\
\text { accepts that experts become an integral part of } \\
\text { the organisation. They belong. In the Australian } \\
\text { context, once trained, experts can be individuals } \\
\text { within the existing organisation. There is an } \\
\text { acceptance of knowledge being transferred. In } \\
\text { the Chinese context, that transference usually } \\
\text { happens at the conclusion of the project." }\end{array}$ & Knowledge Transfer \\
\hline 6 & $\begin{array}{l}\text { "The ERP Revolution: Surviving } \\
\text { Versus Thriving" } \\
\text { Ross(1998) }\end{array}$ & $\begin{array}{l}\text { - "new process teams or process executives were } \\
\text { added to the firm's formal structures" } \\
\text { "Several firms had added new roles such as } \\
\text { data police or a process team, who had } \\
\text { responsibility for ensuring the integrity of the } \\
\text { data and processes and for identifying } \\
\text { opportunities for process change" } \\
\text { "It's very hard for people to change. We find that } \\
\text { the people who were most effective in the old } \\
\text { environment were those who knew how to 'beat } \\
\text { the system.' With SAP, beating the system is not } \\
\text { good; what's good now is discipline. These } \\
\text { people have a lot of unlearning to do and it's } \\
\text { very painful." }\end{array}$ & $\begin{array}{c}\text { Create New Knowledge } \\
\text { Unlearning }\end{array}$ \\
\hline 7 & $\begin{array}{l}\text { "The Identification of Necessary } \\
\text { Factors for Successful } \\
\text { Implementation of ERP } \\
\text { Systems" } \\
\text { Parr, Shanks and Darke(2000) }\end{array}$ & n.a. & n.a. \\
\hline
\end{tabular}

Table 2 Knowledge Lifecycle Activities in ES literature 


\section{The Enterprise System Lifecycle}

In addition to the knowledge lifecycle, ES also have life-spans that spread over a number of phases. The ES lifecycle stresses the specific focus of this framework. Only few publications discuss ES beyond the cost intensive system implementation phase. The following list gives an overview about some ES lifecycle models.

- Bancroft (1996) proposes an ES lifecycle with a focus on the early stages that includes focus, as is, to be, constructing and testing and actual implementation.

- Gable et al. (1998) suggest a lifecycle that consists of consulting process, selecting the ES software, implementing the software and learning and knowledge transfer.

- Markus and Tanis (2000) differentiate along the ES lifecycle between chartering, project, shakedown and onward and upward.

- Ross (2000) discusses in an analysis on the perceived organizational performance into design, implementation, stabilization, continuous improvement and transformation.

- As one suggestion for a consolidation of some of these models, Shanks et al. (2000) propose to distinguish between planning, implementing, stabilization and improvement.

- An example for a software specific approach is ValueSAP (SAP 2000), a framework of methodologies, tools, knowledge, and programs. ValueSAP aims to increase the value out of SAP's ES solution during the entire lifecycle consisting of the three phases discovery and evaluation, implementation and operations and continuous Improvement.

All these approaches have an implementation stage in common. They are similarly elaborated with regards to pre- and post-implementation stages. However, they all lack a definitive stage for the use of the system. This is noteworthy as it is actually the longest phase of the ES lifecycle and unlike all other stages of the ES lifecycle. The use of an Enterprise Systems is the area in which the organization is supposed to benefit the most out of their ES system. "The value of an ES lies not so much in the product itself, but in its effective and efficient usage" (Kremers:2000). Therefore, the lifecycle of an Enterprise System in the framework includes the selection, the implementation, the use and the continuous change of this software.

The selection stage includes the definition of the companies' requirements, a first market overview, a pre-selection of ES solutions, a request for proposals, detailed system evaluation, economic evaluation and final ES selection. The implementation consists of the configuration of the ES software and the introduction of corresponding organizational and technical changes like the definition of new responsibilities or the design of new interfaces (Kirchmer 1999, Keller, Teufel 1998). In relation to the entire life span of Enterprise Systems software, the implementation phase is rather short. Nevertheless, it still usually consumes most of the budget. An ES can be in use for up to 15 years without major changes. In order to execute the ES processes the staff member needs a precise understanding of the software and related business knowledge. In contrast to the implementation, explicit knowledge is more widely available during use of an ES. 
Eventually, an Enterprise System has to be continuously changed as it usually reflects a major part of the organizations' businesses.

\section{A Proposed Framework for Managing ES Knowledge}

In order to structure the knowledge, which is required for the management of Enterprise Systems, a three-dimensional framework is proposed (Rosemann, Chan 2000). This framework has been derived from the afforementioned analyses. Knowledge required in an ES project can be classified along these three dimensions, which are:

- The stages of the knowledge lifecycle: identification, creation, transfer, storage, (re-) use and unlearning of knowledge

- The phases of the ES lifecycle: selecting, implementing, using, and changing the ES

- The types of knowledge required (the knowledge content): business, technical, product, company-specific, project and communication/coordination/cooperation knowledge. Figure 2 shows the principal design of this framework with the three independent dimensions.

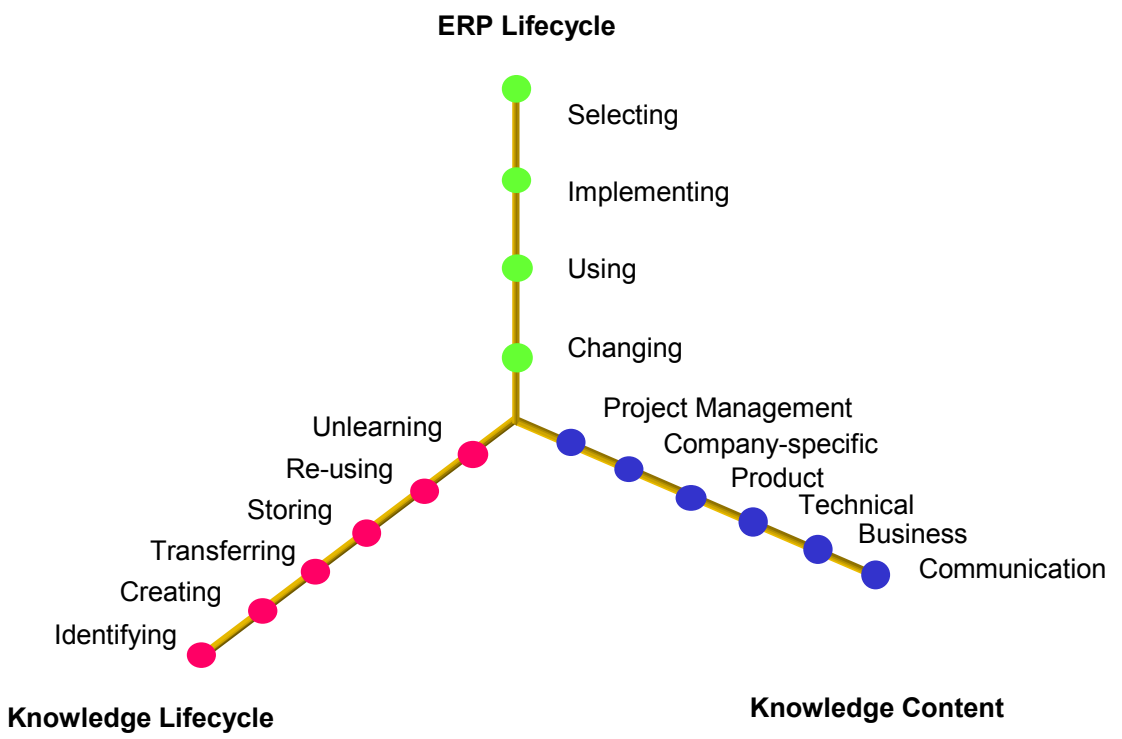

Figure 2. A framework to structure ES-related knowledge

This framework can be used to provide specific knowledge resources timely and independently when needed throughout the implementation phase. This framework would greatly benefit the business and IT industry twofold: one would be is the bettering of knowledge resources whilst the other is in accelerating knowledge acquisition and retaining knowledge resources.

The proposed framework serves as a starting point to analyze and structure the required and the available knowledge. A knowledge manager will be responsible for the 
knowledge lifecycle dimension and information systems that allow the related tasks to be carried out. An ES manager will extend his or her focus to knowledge management in the key tasks of selecting, implementing, using and changing the ES software. Finally, along the knowledge content dimension, the different types of knowledge become obvious. The three dimensions of this framework are discussed in further detail in the following chapters.

\section{Testing the Framework}

\section{Research Questions and Design}

The proposed framework was derived from a comprehensive literature analysis and also includes personal experiences in the area of managing Enterprise Systems. In order to test this framework, an empirical study is currently being conducted. This study has the following objectives:

- Validate every single dimension of the framework: Are the attributes of every dimension complete? Are they redundant? Are certain aspects not relevant?

- Validate the overall framework. Are the dimensions independent from each other? Is any dimension missing?

- Evaluate the importance of the different dimensions and their characteristics.

The designed survey instrument consisted of 8 pages and was structured in correspondence with the proposed framework. Standard personal data and demographic information were collated and information was gathered towards the type and phases in which the Enterprise System in use. The respondents were required to answer questions related to each dimension. The levels of importance were classified into five degrees with each rating given a weight of 1 for "Unimportant" and 5 for "Most Important". Final questions referred to the acceptance of overall framework as well as identifying critical success factors with regards to Managing Knowledge in Enterprise Systems. The survey was first piloted with colleagues at an Australian University. The actual participants were contacted via email list-servers and through personal contacts. The survey was available on the Internet to foster faster receipt of survey results as well as to extend the survey widely across various organizations.

\section{Preliminary results}

The following preliminary empirical results are based on the feedback of the first 10 participants of the questionnaire.

The participants came prominently from managerial and executive backgrounds. Five participants were in the phase of using their enterprise systems, three have not selected an Enterprise System and the remaining participants were in the process of changing and implementing their ES. The participants were asked in the initial part of the survey about the importance of each activity in the knowledge lifecycle in regards to managing knowledge in their respective organizations. They were also asked to express their opinions on other activities that they felt were required to manage knowledge and if they had used any tools to manage knowledge. The second part of the survey required the participants to rate the importance of managing knowledge in each phase of the ES 
lifecycle. Following, the participants were asked to rate the importance of each type of knowledge required for an ES. Open-ended questions towards the end of the survey allowed participants to express their feel of completeness of the proposed framework, identifying critical success factors with regards to Managing Knowledge in Enterprise Systems as well as views and opinions in association with the framework.

From the received feedback, this paper concentrates on the development of "Webgraphs of Importance". The figures below show for each dimension of the framework, the importance of each characteristic perceived by the respondents. Due to the focus and the flavor of the journal and also the constraints of the paper, only results from the Knowledge Life will be discussed.

\section{Knowledge Lifecycle}

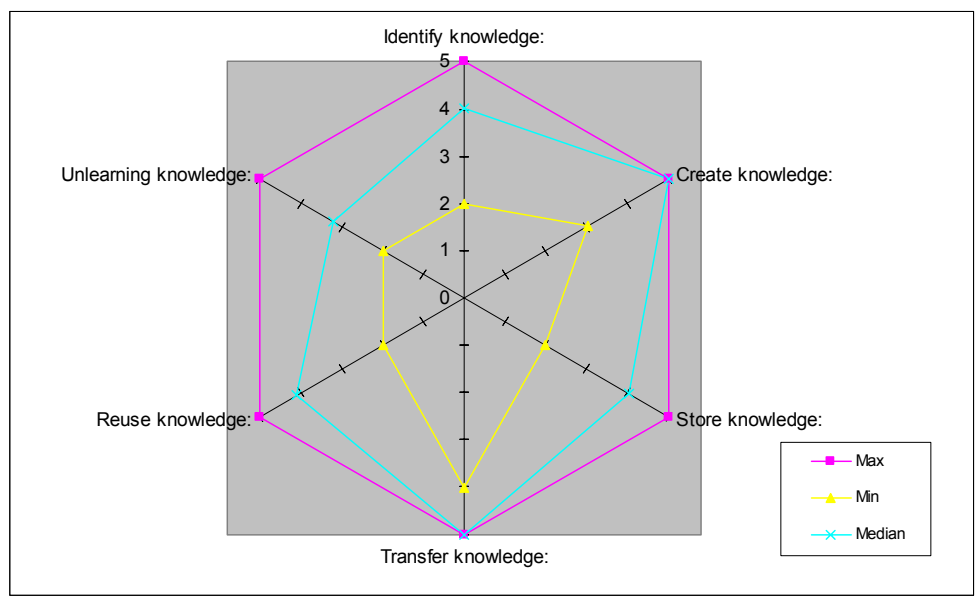

Figure 3: Importance of activities throughout the knowledge lifecycle

The results of the survey show that the participants feel that the activities required for creating new knowledge and transferring knowledge rate score relatively high on the importance scale to managing knowledge in their organizations. It is interesting to note that the activities in the knowledge lifecycle are consistent with a median score of more than 3 but falls steeply into the phase of unlearning knowledge. The possible explanation for this phenomenon could be due the traditional practice and social norm that individuals are unwilling or have the difficulty to unlearn old ways of carrying out tasks. Also, it is found that there is little research in the area of unlearning. It also can be due to the participants' limited experiences with Enterprise Systems.

However and most obviously is the fact that the "value-adding" activities of creating and transferring knowledge are the most important activities in the knowledge lifecycle. "Knowledge transfer involves two actions: transmission (sending or presenting knowledge to a potential recipient) and absorption by that individual or group...The goal of knowledge transfer is to improve an organization's ability to do things, and therefore increase its value"(Davenport:1998). Organizations clearly put emphasis on valuecreating activities like creating new knowledge and transferring knowledge which leads to process innovation. However, in transferring knowledge, organizations will find that the 'hoarding' of knowledge and the incapacity to internalize such knowledge impedes organizational learning. This suggests that tangent studies can be conducted to the field of 
ontology and the cultural aspects of knowledge sharing that are required to overcome this barrier and better facilitate the activities in the knowledge lifecycle.

\section{Enterprise Systems Lifecycle}

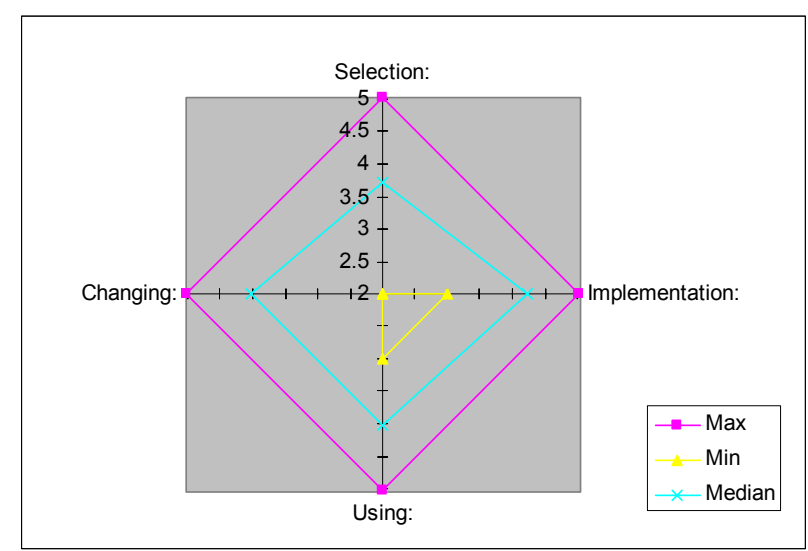

Figure 4: Importance of knowledge management in the stages of the ES lifecycle

The above diagram shows the results of what participants of the survey evaluated as the important phases during the ES lifecycle. These phases require special attention regarding the management of knowledge as different types of knowledge are required during different phases. The preliminary results indicate that the implementation stage is regarding knowledge management the by far most critical phase of the lifecycle. The reasons for this phenomenon might be that:

- the implementation stage is usually a unique and new experience

- the responsible project team usually never worked together before

- the implementation might be the only stage that the participants experienced

- the implementation is the phase that has the greatest impact on the benefits and costs of the Enterprise System

- the implementation of ES usually required the involvement of external experts

Knowledge is seen as crucial to an organization during the implementation phase as it is usually 'new' and unavailable to employees of the organization. Organizations also realize that they rely heavily on external knowledge (consultants). They seek to retain this knowledge within their organization for future use and change of the ES. The results of this study correspond with the intensity in which supporting tools for the different ES lifecycle phase are developed. While the implementation (configuration, customization) is supported by various tools, the selection, use and especially the system change support is rather weak. Kremers (2000) refers the change of an ES to 'migration' and explains that "migration has a bad reputation with the users of ES systems...such projects are timeconsuming and expensive". Thus, ES vendors may be motivated to offer smoother ES change paths and better support tools for their customers. 


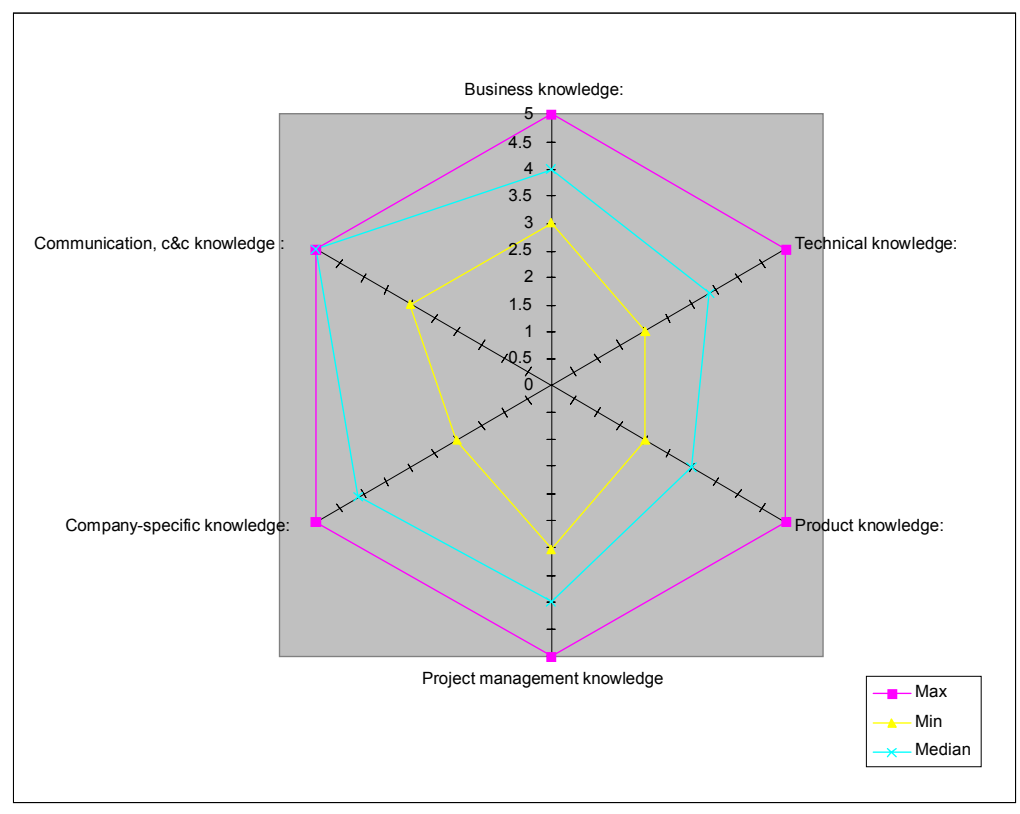

Figure 5: Importance of different types of knowledge

One of the most interesting outcomes of this current research work and future study is the perceived importance of the six different types of knowledge. The preliminary results (Figure 5) highlight the importance of 'soft' knowledge such as communication/ coordination/cooperation knowledge and also project management knowledge. Furthermore, the context sensitive company-specific knowledge is ranked highly. It is interesting to note that the product specific knowledge (e.g. SAP skills), which is often perceived as a bottleneck in ES projects, is ranked together with technical skills as the lowest. Critical success factors (Shanks, 2000) identified by case study participants in the planning phase were "... external expertise: in both SAP processes and technical aspects, and also knowledge of implementation process...". Organizations may have neglected this particular knowledge during the intense implementation and 'go live' of their Enterprise Systems and they may need to put more emphasis on product-specific knowledge to better enhance the efficiency and effectiveness of their ES system.

\section{Conclusion}

This paper proposed a three-dimensional framework for the management of knowledge in Enterprise Systems. The discussion of each dimension of this framework was followed by preliminary empirical results that seek to validate the framework and also to develop an awareness for the more important attributes of the framework in regards to the need for Knowledge Management. These preliminary results have demonstrated some exceptional results such as the importance of value-adding activities and innovation.

Based on more comprehensive feedback, the research aims to develop individual "Webgraphs of importance" for each of the four phases of the Enterprise Systems lifecycle. The assumption is that these results will show how the perceived importance of 
different knowledge management activities and knowledge types changes along the ES lifecycle. The eventual objective will be to synthesize more detailed results specific to each dimension and to finally integrate all three dimensions of the framework. Current research is also currently conducted underway to test the framework by identifying knowledge objects in SAP's Financial module and matching these knowledge areas by mapping them with the use of leading edge modeling tool (ARIS).

\section{References}

AMR Research. "AMR Research Predicts Industrial Enterprise Applications Market Will Reach \$72.6 Billion by 2002", in AMR Research 1998.

Bancroft, N. H. Implementing R/3. How to introduce a large system into a large organization. Manning/Prentice Hall 1996.

Chan, Roy (1999), "Knowledge Management for Implementing ERP in SMEs", 3rd Annual SAP Asia Pacific, Institute of Higher Learning Forum, SAPPHIRE 1999, Singapore, 1-2 November 1999.

Choo, C.W. The Knowing Organization. Oxford University Press 1998.

Clemons, Chr. "Successful Implementation of an Enterprise System: A Case Study," "Proceedings of the 5th Americas Conference on Information Systems.", W. D. Hasemann and D. L. Nazareth (eds.), Milwaukee, WIS., 13-15 August 1999.

Curran, Th., and Keller, G. SAP R/3 Business Blueprint. Understanding the Business Process Reference Model. Prentice Hall PTR. Upper Saddle River, New Jersey 1998.

Davenport, Th. D. "Holistic Management of Megapackage Change: The Case of SAP," in Proceedings of AIS Americas' Conference on Information Systems. 1996.

Davenport, Th. D. Working Knowledge. Harvard Business School Press 1998.

Drucker, F. P. The New Realities. New York: Harper and Row 1989.

Gable, G. G "Large Packaged Software: a Neglected Technology", in Journal of Global Information Management, Vol. 6, 1998, No. 3, Summer 1998, pp. 3-4.

Gable, G. G, Scott, J., and Davenport, Th. D.: "Cooperative EWS Life-cycle Knowledge Management", in Proceedings of the 9th Australasian Conference on Information Systems (ACIS 98), B. Edmundson and D. Wilson (eds.), Sydney, Australia, 29 September - 2 October 1998, pp. 227-240.

Gable, G. G and Stewart, G. "SAP R/3 implementation issues for small to medium enterprises", Proceedings of the 5th Americas Conference on Information Systems, W. D. Hasemann and D. L. Nazareth (eds.), Milwaukee, WIS., 13-15 August 1999.

Gable, G. G, Heever, R. v. d., Erlank, St., and Scott, J. "Large Packaged Software: the need for research", in Proceedings of the 3rd Pacific Asia Conference on Information Systems, Brisbane, Australia, 1997.

Holland, C. P., B. Light, et al. (1999a). A critical success factors model for enterprise resource planning implementation. 7th European Conference on Information Systems, 23-25 June, Copenhagen, Denmark. 
Holland, C. P., B. Light, et al. (1999b). Beyond enterprise resource planning projects: innovative strategies for competitive advantage. 7th European Conference on Information Systems, 23-25 June, Copenhagen, Denmark.

IDS: Methods for Knowledge Management. In: ARIS Methods. Saarbruecken 2000.

Keller, G. and Teufel, Th. SAP R/3 Process Oriented Implementation. Addison Wesley Longman 1998.

Kremers, Mark and Han van Dissel (2000), ERP system migrations. "Communications of the ACM", 2000. Vol. 43 No. 4: pp. 53--56.

Kirchmer, M. Business process oriented implementation of standard software: how to achieve competitive advantage efficiently and effectively, Springer-Verlag, Berlin et al. 1999.

Leonard Barton, D. Wellsprings of Knowledge. Havard Business School Press 1998.

Mahrer, H. "SAP R/3 Implementation at the ETH Zurich", Proceedings of the 5th Americas Conference on Information Systems, W. D. Hasemann and D. L. Nazareth (eds.), Milwaukee, WIS., 13-15 August 1999.

Markus, Lynne and Tanis, Cornelis (2000) "The Enterprise Systems Experience-From Adoption to Success" in R.W. Zmud (Ed.) Framing the Domains of IT Research: Glimpsing the Future Through the Past, Cincinnati, OH: Pinnaflex Educational Resources, Inc.

McGill, M., and Slocum, J. "Unlearning the Organization", Organizational Dynamics, Autumn 1993, pp. 67-78

Myers, S. P. Knowledge Management and Organizational Structure. ButterworthHeineman 1996.

Nonaka, I. "The Knowledge-Creating Company", Harvard Business Review, 1991, pp. 96-104.

Nonaka, I. "A Dynamic Theory of Organizational Knowledge Creation", Organization Science, Vol. 5, 1994, No. 1, February, pp. 14-37.

Nonaka, I., and Hirotaka, T. The Knowledge Creating Company. Oxford University Press 1995.

Rosemann, M. and R. Chan (2000). Structuring and modeling knowledge in the context of enterprise resource planning. 4th Pacific Asia Conference on Information Systems, Hong Kong, Publishing Technology Center, The Hong Kong University of Science and Technology.

Rosemann, M. and J. Wiese (1999). Measuring the performance of ERP software: a balanced scorecard approach. 10th Australasian Conference on Information Systems, Wellington, New Zealand.

Ross J.W., "The ERP revolution: surviving versus thriving," Working Paper, Centre for Information Systems Research, Sloan School of Management, MIT, 1998

Scheer, A.-W.: Business Process Engineering. Reference Models for Industrial Enterprises. Springer-Verlag: Berlin et al. 1998a. 
Scheer, A.-W.: ARIS - Business Process Frameworks. 2nd ed., Springer-Verlag: Berlin et al. 1998 b.

Scott, J., "The FoxMeyer Drugs' Bankruptcy: Was it a failure of ERP?" Proceedings of the 5th Americas Conference on Information Systems, W. D. Hasemann and D. L. Nazareth (eds.), Milwaukee, WIS., 13-15 August 1999.

Shanks, G. et al. (2000) "Differences in Critical Success Factors in ERP Systems Implementation in Australia and China: ACultural Analysis. Proceedings of the ECIS conference.

Sheina, M.: "Knowledge management: Optimizing your ERP investment." EarthWeb www.erphub.com/strategy_000207_KMb.html, (Current May,4, 2000).

Slooten, K. V., and Yap, L., "Implementing ERP Information Systems using SAP", Proceedings of the 5th Americas Conference on Information Systems, W. D. Hasemann and D. L. Nazareth (eds.), Milwaukee, WIS., 13-15 August 1999.

Sumner, M. "Critical Success Factors in Enterprise Wide Information Management Systems Projects", Proceedings of the 5th Americas Conference on Information Systems, W. D. Hasemann and D. L. Nazareth (eds.), Milwaukee, WIS., 13-15 August 1999.

Weiss, W. J., and Wysocki, R. K., 5-phase project management: a practical planning \& implementation guide. Addison-Wesley 1992. 